Images In...

\title{
Hairy polyp of the nasopharynx causing chronic middle ear effusion
}

\author{
R Zakaria, N R T Drinnan, R S Natt, R Temple
}

ENT, Countess of Chester Hospital NHS Foundation Trust, Chester, UK

Correspondence to R Zakaria, rzakaria@nhs.net

\section{DESCRIPTION}

Hairy polyps of the nasopharynx were first described by Arnold in 1870 with differentiation made between teratomas, teratoids, epignathi and hairy polyp. The pathogenesis of hairy polyps is not clearly understood but they are thought to arise from the embryonic ectodermal and mesodermal layers and may contain glandular tissue, muscle, cartilage, bone or lymphatic tissue. ${ }^{12}$ The symptoms of hairy polyps relate both to their location and their size. Larger lesions produce symptoms due to feeding difficulties and airway obstruction while smaller lesions cause intermittent symptoms resulting from a ball-valve type of obstruction.

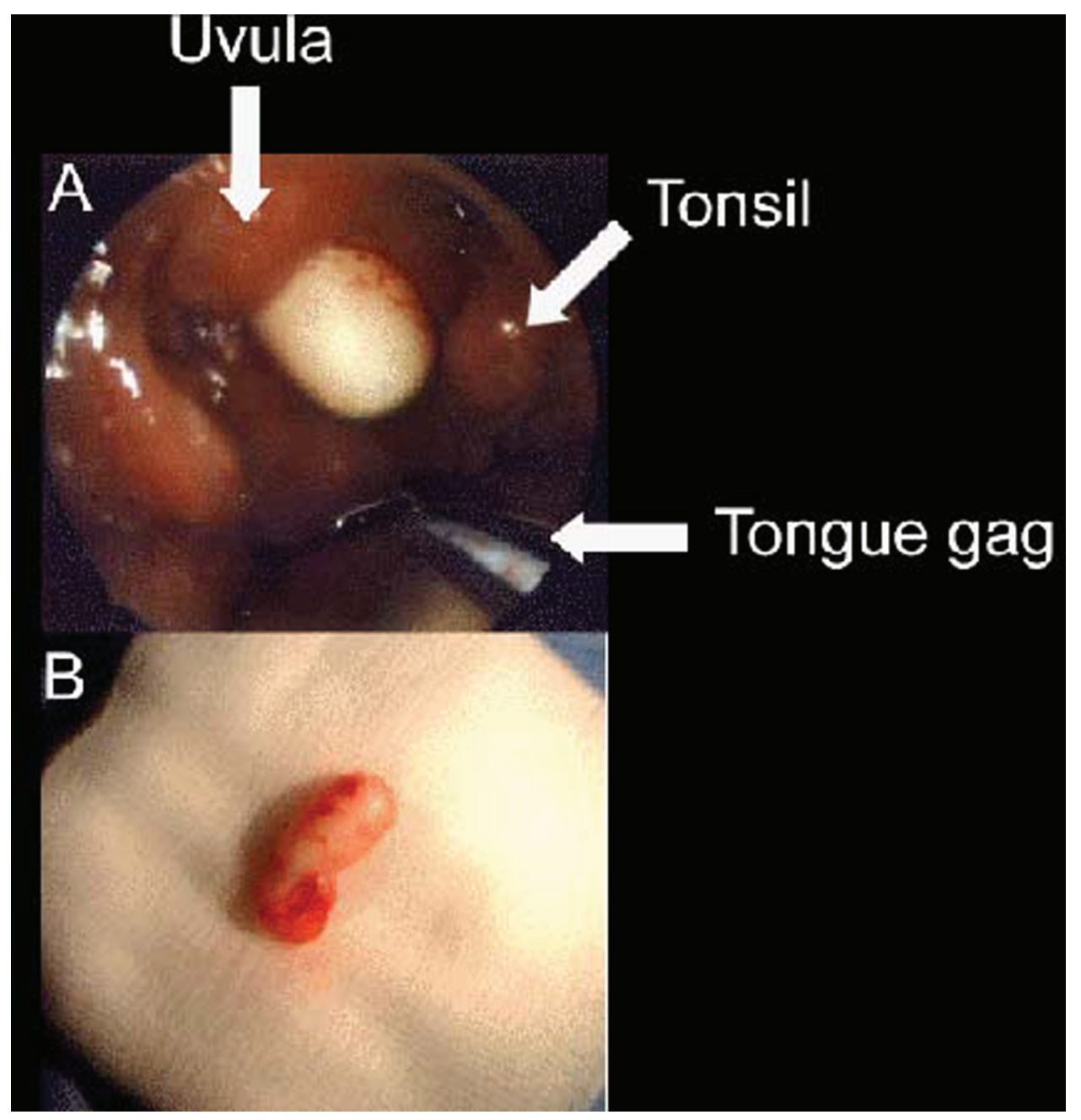

Figure 1 A 2-year-old boy was reviewed in the outpatient department with a history of snoring and chronic middle ear effusion. Examination of the oral cavity revealed a pedunculated polypoid mass occupying the postnasal space (A). The lesion was completely excised in theatre under general anaesthetic. Macroscopic photograph of the specimen is shown in the photograph (B); histology was reported as 'hairy polyp.' The child was well postoperatively with complete resolution of his chronic middle ear effusion and sleep apnoea. There has been no sign of recurrence of the lesion at 6 month review. 


\section{BMJ Case Reports}

Obstruction of the airway during sleep commonly occurs as a result of enlarged adenoids or tonsils, rhinosinusitis, polyposis, myopathies and cystic fibrosis. Equally, chronic middle ear effusion (CMEF) is a common condition seen in children and is associated with a number of causes. However, CMEF and sleep apnoea are rarely attributable to tumours of the nasopharynx. ${ }^{3}$

Traditionally, history taking and clinical examination have been sensitive and specific enough to accurately diagnose and subsequently treat CMEF and sleep apnoea. More recently, tympanography, tympanocentesis and sleep studies have been used in order to quantify the severity of these conditions, but act predominantly to confirm the surgeon's most likely differential. Similarly, laboratory investigation, such as erythrocyte sedimentation rate and full blood count, will rarely alter the management of the condition.

When assessing a soft tissue mass in the nasopharynx, imaging may be useful in both diagnosis and operative planning. MRI is particularly useful in delineating the degree of soft tissue extension. The typical MRI appearance of a polyp is of a non-enhancing, well-defined mass with a relatively homogeneous matrix surrounded by a smooth capsule. CT also plays a role defining the bony anatomy of intracranially invasive lesions and excluding pathologies associated with CMEF such as mastoiditis and cholesteatoma.

Hairy polyps, although uncommon, need to be included in the differential diagnoses for both CMEF and sleep apnoea. In addition to clinical examination, modern imaging techniques allow for accurate preoperative planning in order to optimise surgical management.

Competing interests None.

Patient consent Obtained.

\section{REFERENCES}

1. Nicklaus PJ, Forte V, Thorner PS. Hairy polyp of the eustachian tube. J Otolaryngol 1991;20:254-7.

2. Jarvis SJ, Bull PD. Hairy polyps of the nasopharynx. J Laryngol Otol 2002;116:467-9.

3. Phansalkar M, Sulhyan K, Muley P, et al. Hairy polyp of nasopharynx-a case report. Indian J Pathol Microbiol 2000;43:355-6.

This pdf has been created automatically from the final edited text and images.

Copyright 2010 BMJ Publishing Group. All rights reserved. For permission to reuse any of this content visit http://group.bmj.com/group/rights-licensing/permissions.

BMJ Case Report Fellows may re-use this article for personal use and teaching without any further permission.

Please cite this article as follows (you will need to access the article online to obtain the date of publication).

Zakaria R, Drinnan NRT, Natt RS, Temple R. Hairy polyp of the nasopharynx causing chronic middle ear effusion. BMJ Case Reports 2010; 10.1136/bcr.08.2010.3244, date of publication

Become a Fellow of BMJ Case Reports today and you can:

- Submit as many cases as you like

- Enjoy fast sympathetic peer review and rapid publication of accepted articles

- Access all the published articles

- Re-use any of the published material for personal use and teaching without further permission

For information on Institutional Fellowships contact consortiasales@bmjgroup.com

Visit casereports.bmj.com for more articles like this and to become a Fellow 